Chapman University

Chapman University Digital Commons

Education Faculty Articles and Research

College of Educational Studies

3-26-2017

\title{
From Liberation to Salvation: Revolutionary Critical Pedagogy Meets Liberation Theology
}

Peter McLaren

Chapman University, mclaren@chapman.edu

Petar Jandrić

Zagreb University of Applied Sciences

Follow this and additional works at: http://digitalcommons.chapman.edu/education_articles

Part of the Christianity Commons, Curriculum and Social Inquiry Commons, Inequality and Stratification Commons, Latin American Languages and Societies Commons, Latin American

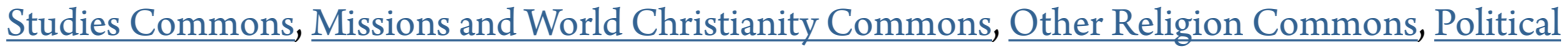
Theory Commons, Politics and Social Change Commons, Practical Theology Commons, Race and Ethnicity Commons, Religious Thought, Theology and Philosophy of Religion Commons, $\underline{\text { Sociology of Culture Commons, and the Sociology of Religion Commons }}$

\section{Recommended Citation}

McLaren, P., \& Jandrić, P. (2017). From liberation to salvation: Revolutionary critical pedagogy meets liberation theology. Policy Futures in Education, 1478210317695713. https:// doi.org/10.1177/1478210317695713

This Article is brought to you for free and open access by the College of Educational Studies at Chapman University Digital Commons. It has been accepted for inclusion in Education Faculty Articles and Research by an authorized administrator of Chapman University Digital Commons. For more

information, please contact laughtin@chapman.edu. 


\section{From Liberation to Salvation: Revolutionary Critical Pedagogy Meets Liberation Theology}

\section{Comments}

This is a pre-copy-editing, author-produced PDF of an article accepted for publication in Policy Futures in Education in 2017 following peer review. The definitive publisher-authenticated version is available online at DOI: $10.1177 / 1478210317695713$

\section{Copyright}

The authors 


\title{
From liberation to salvation: Revolutionary critical pedagogymeets liberation theology
}

\author{
Peter McLaren
}

Chapman University, USA

Petar Jandrić

Zagreb University of Applied Sciences, Croatia

\begin{abstract}
This conversation between Peter McLaren and Petar Jandric brings about some of the most recent and deepest of McLaren's insights into the relationship between revolutionary critical pedagogy and liberation theology, and outlines the main directions of development of McLaren's thought during and after Pedagogy of Insurrection. In the conversation, McLaren reveals his personal and theoretical path to liberation theology. He argues for the relevance of liberation theology for contemporary social struggles, links it with social sciences, and addresses some recent critiques of Pedagogy of Insurrection. McLaren identifies the idolatry of money as the central point of convergence between liberation theology and Marxism. Developing this thought further, he asserts that Jesus was a communist. McLaren analyses the revolutionary praxis of liberation theology in Latin America, and concludes that the struggle needs to avoid violence and endure without losing tenderness. He analyzes the international politics of liberation theology and shows that liberation theology was demonized by the US administration because it works for the poor. McLaren then expands experiences from Latin America towards a global ethics of solidarity, criticizes Church positions on various matters, and insists on a critical approach to Church dogmas. He explores theoretical and practical dissonances between Marxism and Christianity, and expands them towards a more general dichotomy between the material and the spiritual. $\mathrm{He}$ explores the Christian eschaton - the arrival of the Kingdom of God - and links it to Marx's prophecy of the future socialist society. Finally, he explores ecumenical opportunities of liberation theology and firmly links it with the arrival of the socialist society.
\end{abstract}

Keywords

Liberation theology, revolutionary critical pedagogy, communism, ethics of solidarity, Marxism, Christianity

Corresponding author:

Petar Jandrić, Zagreb University of Applied Sciences, Vrbik 8, Zagreb, I0000, Croatia.

Email: pjandric@tvz.hr 


\section{Introduction}

Petar Jandrić (PJ): For anyone interested in critical pedagogy, Peter McLaren needs no introduction. As the "intellectual relative" of Paulo Freire (Freire, 1995: X), and one of the leading architects of contemporary critical pedagogy, Peter has left an invaluable mark in the past and present of the educational left. Yet, Peter has never looked backwards. Instead of lulling in the well-deserved secure position of a senior intellectual, in 2015 he published the ground-breaking book Pedagogy of Insurrection (McLaren, 2015) which develops a new emancipatory praxis at the crossroads between revolutionary critical pedagogy and liberation theology. Unsurprisingly, the book has immediately provoked a lot of attention. Some critics praised Peter's intellectual boldness and strength; other critics have attacked his thought in various ways and almost reached the level of hate language. The third group, and I readily admit to belong to that group, was confused, curious, yet careful. Brought up in ex- communist East Europe, and myself deeply conflicted about religion, I could not help but ask: How is it possible that someone like Peter McLaren has made such a bold move towards religion and spirituality? What are the underlying reasons behind this move?

During the past few years, Peter and I have co-written several conversational pieces (i.e. McLaren and Jandrić , 2014, 2015). For the purpose of republishing one of these pieces in my forthcoming book (Jandrić, 2017), I wanted to update the text with Peter's insights in liberation theology. In the hope to get an additional page or two for the existing article, in Autumn 2016 I emailed Peter few questions. In only a couple of days, however, I received almost 10,000 words of Peter's writing at its best - sharp, bold, powerful, straight to the point testimony of many years of deep thinking about the relationship between revolutionary critical pedagogy and liberation theology. Peter's initial answers provoked more questions, then more answers, then even more questions ... after several days of furious email exchange, this text had finally arrived into being.

Peter and I immediately understood that this conversation is much more than a mere extension of our ongoing work. Instead of rephrasing the content of his recent book, in this article Peter responds to a lot of critical feedback to Pedagogy of Insurrection (McLaren, 2015), looks into the historical roots of liberation, presents fresh ideas, and answers questions emerging from his recent work. Thus, this conversation brings about some of the most recent and deepest insights of Peter McLaren into the relationship between revolutionary critical pedagogy and liberation theology, and outlines the main directions of development of Peter's thought during and after Pedagogy of Insurrection (McLaren, 2015).

Peter McLaren (PM): I have greatly enjoyed working with you and since meeting you both online and in person have admired your keen intellect and your commitment to social justice in your work. My work over the past 30 years has been primarily in critical theory, critical pedagogy, Marxist humanist philosophy, and more recently, liberation theology. I look forward to our discussion.

\section{The path to liberation theology}

PJ: Please describe your personal journey to liberation theology, Peter. Did you experience some kind of transcendental experience; did you arrive to liberation pedagogy by the way of intellectual development; or perhaps both?

PM: I am aware that many of your readers might be unfamiliar with the political history of South America, so please permit me to provide some context for my discussion of the 
theology of liberation. Before I begin, I need to tell you that I have not had any formal training in theology but as a Catholic convert and a Marxist educator, I have for a long time followed the work of a number of theologians associated with this tradition. In my teenage years I contemplated going into the priesthood but became swept away by the indulgences of every kind and stripe that were available in the 1960s and my life has been anything but priestly. I converted to Catholicism later in my life, in my $30 \mathrm{~s}$, having been raised an Anglican. But my mother, Frances Teresa Bernadette McLaren was, as you might guess from her name, Catholic and my father, Lawrence Omand McLaren, was brought up Presbyterian. They wanted to raise me in a religious tradition separate from theirs.

I became serious about revolutionary politics about the time of my conversion to Catholicism and at the same time I was drawn to numerous spiritual traditions. Around this time, too, I was receiving invitations to speak in Latin America and the Caribbean, eventually over the years working with educators and activist groups in Argentina, Mexico, Peru, Brazil, Colombia, Venezuela, Cuba, Puerto Rico, etc. Well, the late 1960s, 1970s, and 1980s were especially brutal years for campesinos, workers, activists, teachers, and revolutionaries throughout Latin America, especially in the Southern Cone. After the government assassination of six Jesuit scholars, their housekeeper and her daughter on 16 November 1989 on the campus of Universidad Centroamericiana in San Salvador, El Salvador, the world finally started to take serious notice, especially since the Archbishop of San Salvador, Oscar Romero, had been assassinated in 1980 while offering mass in the chapel of the Hospital of Divine Providence after famously speaking out against poverty, social injustice, and torture.

PJ: During recent years, you often visited Venezuela and conversed with the late president Hugo Chá vez. Were you involved with the Catholic Church during your visits to

Venezuela? PM: No, I did not make any connections with Catholic organizations during my visits.

The limited but highly influential times that I spent in Venezuela were important in my formation as a revolutionary mostly by learning - despite my limited Spanish - from the local people. And while I remain a supporter of the Bolivarian revolution I acknowledge that there have been serious mistakes. For example, I was never supportive of Chavez's relationship with Iran, nor do I support the peace prize that Chavez's successor, President Maduro, presented to Vladimir Putin recently - especially given that at this very moment Putin is helping Assad to massacre thousands of innocent civilians in Aleppo. Russia's involvement in the Ukraine and its annexation of Crimea and the death squads in Russia exterminating political opponents are all disturbing realities. Yes, I understand the method in the madness and the concept of "the enemy of my enemy is my friend." In addition, the award to Putin is likely a reaction to the peace prize given to Colombian President Santos, clearly no friend of Maduro. And I am sure Maduro was not happy with the role of Cuba in helping Santos negotiate the peace deal with the Revolutionary Armed Forces of Colombia (FARC). A deal which, by the way, was rejected by the Colombian people in a recent vote.

PJ: Can you place your personal path towards liberation theology in a broader historical perspective?

PM: Of course, much had been happening in Latin America and the Caribbean long before the abovementioned atrocities were reported in the international press - if we want to be historically expansive, we could say that the problems began with the European colonization of Las Americas, beginning in 1492 when the indigenous populations were enslaved or exterminated. But in more recent times we need only to look at Cuba. When Cuba moved to a people-centered economy in 1959, the USA organized the Bay of Pigs 
invasion, and in the ensuing years throughout Latin America the USA has been behind the establishment of military regimes that included Chile, Uruguay, Brazil, and Argentina. As early as 1969, The Rockefeller Report (The Rockefeller Foundation, 1969) identified liberation theology as a threat to the corporate interests and the security of the USA.

Then there was the clandestine Operation Condor (Operación Cóndor or Plan Cóndor; McSherry, 2005) that was a major plan of interservice and regional cooperation and a sharing of joint intelligence among the USA and the right-wing dictatorships of the Southern Cone of South America, including Argentina, Chile, Uruguay, Paraguay, Bolivia, and Brazil, in order to maintain an intelligence-sharing program of state terror and political repression. The program began in 1968 but was fully implemented by 1975 and was responsible for as many or more than 60,000 deaths up until 1989. In Argentina alone over 150 priests and nuns were killed, along with peasants, workers, intellectuals, and anyone associated with being part of or sympathetic towards leftist guerilla movements. The program - which can be traced to the infamous US School of the Americas (renamed the Western Hemisphere Institute for Security Cooperation because of its historical association with the training of Latin American death squads) - was created to advance joint counterinsurgency operations designed to eradicate communist subversives and ideas, and to suppress the influence of liberation theology and other oppositional political or ideological positions.

Through the Central Intelligence Agency (CIA), the US military, and the State Department, the US government helped to bring military dictatorships to power and secure their stability by imposing sanctions to destabilize the economies of socialistleaning regimes and by supporting and training "black op" and execution squads. While the USA was not an official member of the Condor consortium, documents that were later uncovered revealed that during this time the USA provided major organizational, financial, and technical assistance to the repressive regimes involved. The secret papers of the 17th Conference of American Armies in Mar del Plata in 1987 revealed that the US military initiated numerous discussions about how to wage socio-psychological warfare against liberation theology, ecclesial, and base communities through LIC (Low Intensity Conflict) strategies using misinformation and ideological subversion (Duchrow, 1999). Of course, when the assassinations of the Jesuits broke into the news there was international pressure to shut down the death squads.

PJ: What caused so much resistance towards liberation theology? Why was it so threatening?

PM: Why was liberation theology so threatening? To answer that question we need to consider The Conference of Latin American Bishops that was held in 1968 in Medellí n, Colombia. It was here that bishops from all over Latin America agreed that the church should take "preferential option for the poor." The bishops decided to form Christian base communities in which they would create literacy programs, and this captured the attention of Paulo Freire. The goal of the bishops was to support conditions so that the poor could liberate themselves from the "institutionalized violence" of poverty. The year that marked the beginning of Operation Condor was the same year - 1968 - that this conference in Medellí n, Colombia, took place. What emerged from this conference was to become known as liberation theology.

However, John Paul II was very much opposed to communism and he considered liberation theology a dangerous development within the Church. In the late 1970s, shortly after he was elected Pope, he began to oppose liberation theology directly and the church 
hierarchy moved decidedly to the right. He put Joseph Cardinal Ratzinger (later Pope Benedict XVI) in charge of countering the theological interpretations and actions of liberation theologians. It was no accident that Pope John Paul II made numerous trips to Latin America. In 1983, the Pope visited Nicaragua to scold Father Ernesto Cardenal and to oppose liberation theology. I had the good fortune of meeting Ernesto Cardenal on a television show hosted by President Hugo Chavez in 2006. John Paul II defrocked Cardenal because of his participation in liberation theology. Fortunately, Pope Francis overturned this decision in 2014.

\section{Pedagogy of insurrection}

PJ: Based on this brief historical introduction, let us jump into the moment here and now. Immediately after publishing, Pedagogy of Insurrection (McLaren, 2015) provoked a lot of attention. For instance, it came under heavy attack from a radical leftist anarchist educator, who claims that your work in the field of liberation theology is well below the standards for social science research. Can you please respond to this argument? What makes liberation theology real, alive, and relevant for social science and beyond?

PM: Well, one question would be: Are we talking about the Hegelian conception of science - dialectical reasoning - or the vulgar empiricist conception of science? Marx's concept of "value," for instance, has nothing to do with corporeal existence. Value is not a thing but a relationship. Dialectical reasoning brings "internal relations" to the forefront, which cannot be reduced to things - this issue needs to be interrogated from a different epistemological standpoint. And from an ethical standpoint - from the standpoint of the dispossessed, from the perspective of the oppressed, and also from the standpoint of the oppressor. It cannot remain neutral. Liberation theology displays a praxiological dimension of thought and action coming together to transform the world in the interests of justice. God becomes visible when people put their lives on the line for others, especially when they sacrifice themselves for those who are most vulnerable to exploitation and alienation and the ravages of capitalism. Vulgar empiricism and materialist dogmatism cannot help us grasp the idea behind the transaction between the capitalist and the laborer. What is sold in this exchange, Marx tells us, is not labor - but labor power. There is plenty of pseudoMarxist theory out there, as well as anarchist theory that claims that theology is a flabby discipline. Of course, there is flabby theology, but it would be impertinent and glib to claim this for all theological traditions.

I think social science is very relevant for theology, and vice versa. Just as Marx's work revolutionized the science of history in his discovery of the workings of the mode of production by means of scientific dialectics, so Christian theology has revolutionized our understanding of faith. Theology challenges positivistic science and empiricism, but that does not render it unscientific. Liberation theologians may challenge the materialism of the anti-Hegelians, or they may take a different approach. Certainly, the principles of natural science are not the only principles by which to verify truth. But liberation theology needs social science as much as social science needs theology. We need to understand the world in order to change it - after all, this was a major imperative for Marx as it was for Jesus. Jesus taught us not through social science theories but through parables.

PJ: Theology and (social) science are written using radically different languages therefore, we need to read them in radically different ways. Most of our readers will be 
familiar with reading one or another language of science. How should we go about reading the gospels?

PM: Both Jesus and Marx maintained a commitment to the poor and the powerless. In the case of Jesus, his story is the embodiment of the word of God. Theology helps us to gain a deeper understanding of the meaning of Jesus' life. Jesus comes to the encounter with the divine a new praxis, an incarnation that radiates love through a concretization of prophetic justice. Of course, when we attempt to fathom the paschal mystery, we are guided by our own history, our own formation, what the Germans refer to as Bildung. Here we adhere to historico-critical exegesis with an understanding that a purely scientific exegesis does not eliminate divergent interpretations, since it is impossible to rid ourselves of all of our theologio-dogmatic presuppositions. When we read the scriptures we have to acknowledge that our interpretations are guided by our own biographies and by suffering Christian communities throughout the ages who read the gospels through contextually specific eschatological, soteriological, and Christological themes - mainly with a kerygmatic intention. As Leonardo Boff (1987) would put it, reading the gospels is not the same as reading facts of history, because in such a reading you are dealing with history, the interpretation of history, and a profession of faith working together to understand the totality of Christianity from an apologetical viewpoint. Christ destroys all of our previous images of God, as Christ suffers for all the crucified of history. As Boff (1987) notes, this is a mystery inaccessible to discursive reason but capable of being understood through human praxis. We are resurrected through our refusal to cooperate with the social sin of this world.

Remember, Petar, that Paulo Freire wrote that the prophetic position of the Church "demands a critical analysis of the social structures in which... conflict takes place. This means it demands of its followers a knowledge of socio-political science, since this science cannot be neutral; this demands an ideological choice" (1973: 14). Here Freire admits to the notion that all science is a form of ideology and that there is an ideological choice in choosing particular types of science with which to clarify and deepen our understanding of the struggle for liberation. Part of the prophetic vision of the Church demands an engagement with social science that can help unpeel the veneer of mystification that keeps us from knowing reality. Freire writes that a prophetic perspective "does not represent an escape into a world of unattainable dreams. It demands a scientific knowledge of the world as it really is" (1973: 14). But note that for Freire, this scientific understanding of the world is found through praxis, through revolutionary praxis. Freire warns that "to denounce the present reality and announce its radical transformation into another reality capable of giving birth to new men and women, implies gaining through praxis a new knowledge of reality" (1973: 14). Freire criticizes the petit bourgeois dimension of the Church today and urges theologians to consider in their work the so-called Third World that exists within their own so-called First World - in the outskirts of their cities. And I would add - within our segregated inner cities.

PJ: Speaking of Pedagogy of Insurrection (2015), you have been attacked by a former admirer of your work as no better than historical tyrants who use God as a cover for their crimes. This is because you "came out" as a devout Catholic and very likely many of your leftist admirers assume you are an atheist. This kind of argumentum ad hominem is obviously wrong. Yet, I completely agree with Derek Ford's review, which says that publishing Pedagogy of Insurrection "is certainly a risky move for McLaren, for he risks both the condemnation of the Christian right as well as contemporary atheists. Interestingly, these two groups have quite a bit in common" (Ford, 2016). 
What is the connection between left-wing and right-wing critiques of your work? Here, I am especially interested in critiques arriving from the left: the closer they are, the more they hurt. Some left-wing theorists, especially those arriving from anarchist circles, say that religion and capitalism are mutually foundational - in this view, religion simply does not work together with socialism. What do you make of this critique? How, and under which condition, can we divorce religion from capitalism and build a theist socialist future?

PM: I regard the particular attack to which you refer as an example of what Lenin would call an infantilism of the left. Which is not to say I regard all atheists in this way, far from it. But let us get to the bigger picture here. Of course I agree with Herbert Marcuse (2011) when he wrote in "The role of religion in a changing society" that no evaluation of that role can be made without meeting Marx's criticism of religion. I have never veered from this position. But Christianity, as Miranda notes (1974, 1980, 2004), is not something that should be absorbed into a religion. Marx attacks Christianity to the extent that it has been calcified into a religion. Marx was certainly anti-clerical but both Marx and Engels, I believe, saw their work as a continuation of the authentic message of Jesus. Marx applied the term "Christian" to himself in a letter to Ludwig Kugelmann in 1870, constantly made Biblical references throughout his works, and compared the persecutions against the international as the persecutions of primitive Christians by the Romans.

As a revolutionary Marxist humanist who works in the tradition of critical pedagogy, which I have developed over the years as "revolutionary critical pedagogy" - and as a Catholic - I have been greatly influenced by the work of the great Jesuit theologian and educator Jose Porfirio Miranda. So much of what I am offering as a response to your question is indebted to his work, especially his classic work, Marx against the Marxists (Miranda, 1980), that readers will need to seriously engage this work in order to get the details. In his world-shaking critique of capitalism, Marx regards people as endowed with the capacity to make history. Marx affirms "the cunning of reason" as the means by which human actors shape history. This type of reason is neither an abstraction, nor is it attached to the notion of history as some kind of abstract entity of its own that floats above the messy web of human strife and turmoil. Reason in this larger sense has, according to Marx, created the conditions of possibility for a truly humane society to emerge out of the ruins of capital. But the foundational issue here is: Why must a new society emerge from the extraction of surplus value from alienated labor?

The destruction of capital becomes, for Marx, the immanent form for a higher principle that makes possible capitalism's ability to cede its place to a communist society. Marx's entire corpus of works is orientated towards this historical eschatology in his denunciation of the worship of the god of money. The cunning or subtlety of reason creates the conditions of possibility for results that are contrary to those which the capitalists were pursuing. Miranda is very convincing here when he affirms that Marx appeals to this eschatological aspect of history - this affirming of the eschaton or Kingdom of God of which Jesus preached. This eschaton is occurring in history itself and not in some other world, some cosmic hinterland where people float around as disembodied spirits. Churches and Christians everywhere tragically refuse to hear this message. Marx has this eschatological awareness, his writings are full of it, and I do not have space here to recite all the instances in his writings where this is evident - they can be found in the works of Miranda.

PJ: Can you say a bit more about the eschatological aspect of history? How can it be confirmed; how does it link to liberation? 
PM: We cannot affirm the existence of an eschaton unless we affirm the existence of a God guiding history. The eschaton for Christ meant that injustice and exploitation will disappear once and for all. Atheists reject the eschaton, clearly. I hold that both Jesus and Marx maintained the reality of the eschaton. Engels and Marx's work reveal this both implicitly and explicitly. The reason immanent in history is God. This I believe is reflected in the notion of hope that can be seen in the writings of both Marx and Engels. Clearly Marx understood Kant's categorical imperative as "bad infinity," that is, the eternal return of the same in which an imperative is reiterated but is never fully realized. Marx rejected Kant's antieschatological and anti-messianic attitudes of eternal deferment and postponement. And what about Hegel? Marx had a profound critique of Hegel's work but he did not dismiss Hegel's affirmation of the final end of history through an intervening Absolute that can bring the endless return of the same to a halt.

God is the intervening Absolute who relativizes the eternal return of the same and delinks us from it so that we can seize the torch of liberation. Jesus came to revolutionize the social structure of religion, not to occupy a throne reserved for him by "religious" functionaries of the state who have been made illustrious in the capitalist world by their unslakable thirst for power and class privilege. As Miranda argues, rebellion against religion is mandatory for anyone who wants to bring justice to the world. Charles Reitz, who has adumbrated a Marxist atheist position, is correct here in arguing for a communal politics of justice and commonwealth by means of a dialectical sublation of religion, surpassing its inadequacies yet preserving its worthwhile historical contributions. Here, Reitz (2015) starts with humanity's oldest philosophical and religious sources in Africa that reflects that "communally laboring humanity can be seen as the source of ethics." This ethics of caring, reciprocity, and the "golden rule" includes emancipatory religious practice, as in the civil rights movement. Here the struggle for justice includes the struggle against racism, sexism, patriarchy, and capitalism. Can we not hear the words of Jesus: "Woe to you rich, for your consolation is now" (Luke 6: 24) or "Blessed are you poor; the reign of God is yours (Luke 6:20)?

\section{The idolatry of money}

PJ: In regards to religion, various leftist traditions significantly collide - Paulo Freire was a deep Christian believer, while Marx famously proclaimed religion as "the opium of the people" (Marx, 1970 [1843]). Your work is deeply situated in both traditions, and Pedagogy of Insurrection (McLaren, 2015) clearly leans towards the Latin American approach that sees Christianity as compatible with, and even beneficial to, revolutionary critical pedagogy. What are the reasons behind such direction of development of your thought?

PM: Freire has addressed the role of theologians and the Church - its formalism, supposed neutrality, and captivity in a complex web of bureaucratic rites that pretends to serve the oppressed but actually supports the power elite - from the perspective of the philosophy of praxis that he developed throughout his life. For Freire, critical consciousness (conscientization) cannot be divorced from Christian consciousness. Freire's attack on bourgeois subjective idealism as "nai" ve consciousness" approaches the transformation of consciousness as a political act: to speak a true word, according to 
Freire, is to transform the world. The ruling class, from Freire's perspective, views consciousness as something that can be transformed by "lessons, lectures and eloquent sermons" (1973: 2). In this instance consciousness is essentially static, necrophilic (deathloving) as distinct from biophilic (life-loving), constitutes "an uncritical adherence to the ruling class" (1973: 2), and serves as a means of "emptying conscientization of its dialectical content" (1973: 3).

Freire calls for a type of class suicide in which the bourgeoisie take on a new apprenticeship of dying to their own class interests and experiencing their own Easter moment through a form of mutual understanding and transcendence. Freire argues that the theologians of Latin America must move forward and transform the dominant class interests in the interests of the suffering poor "if they are to experience 'death' as an oppressed class and be born again to liberation" (1973: 6). Or else, they will be implicated within a Church "which forbids itself the Easter which it preaches" (1973: 5-6). Freire borrowed the concept of "class suicide" from Amilcar Cabral, the Guinea-Bissauan and Cape Verdean revolutionary and political leader who was assassinated in 1973. For Freire, insight into the conditions of social injustice of this world stipulates that the privileged must commit a type of "class suicide" where they self-consciously attempt to divest themselves of their power and privilege and willingly commit themselves to unlearning their attachment to their own self-interest. Essentially, this was a type of Easter experience in which a person willingly sacrifices his or her middle or ruling class interests in order to be reborn through a personal commitment to suffering alongside the poor.

Of course, this class suicide takes place in the context of a larger mission to end the social sin of poverty itself. It is a transformational process in which a person identifies with the poor and the oppressed and commits oneself to taking down all victims from the cross. Here we find an echo of the teachings of St Francis. Both Freire and St Francis understood that a transcendence of oppression - a striving upwards - in the struggle for liberation was not enough. As Leonardo Boff notes in his study of St Francis, a striving "upwards" away from the travails of the world through the attainment of a mystical consciousness is not enough. What is also needed, and even more so, is a "trans-descendence" - a kenotic act of selfemptying, an openness to the lives of those below - the poor, the stigmatized, the despised and a willingness to integrate them into a community of love, kindness, and solidarity - a fraternal solidarity with those suffering from the scourge of life's deprivations. Christ encountered such trans-descendence in the wretched of the earth, in the crucified of history.

PJ: In theory, the concept of class suicide somehow seems much more viable than in practice... How can we move on from theory to praxis?

PM: Let us examine some of Freire's positions here. Freire writes that the praxis by which consciousness is changed "is not only action but action and reflection" (1973: 3). He argues that theoretic praxis is only authentic when it maintains the dialectical movement between itself and the contextual specificity of the praxis one wishes to carry out, that is, when it is cognizant of the unity between practice and theory in which both are constructed, shaped, and reshaped. Authentic praxis, in other words, is a "dialectical movement which relates critical reflection on past action to the continuing struggle" (1973: 4). For Freire, a pedagogy of liberation involves "social praxis" that is all about "helping to free human beings from the oppression which strangles them in their objective reality" (1973: 4). Social praxis, as explained by Freire, is what drew me to the Latin American tradition of liberation 
theology, a theology that encourages the oppressed to create and recreate themselves in history in a concrete fashion rather than participate in what Freire calls "a reformed repetition of the present" (1973). Freire writes:

I cannot permit myself to be a mere spectator. On the contrary, I must demand my place in the process of change. So the dramatic tension between the past and the future, death and life, being and non-being, is not longer a kind of dead-end for me; I can see it for what it really is: a permanent challenge to which I must respond. And my response can be none other than my historical praxis-in other words, revolutionary praxis. (1973: 7)

\section{PJ: In Pedagogy of Insurrection, you write:}

Critical pedagogy is the lucubration of a whole philosophy of praxis that predates Marx and can be found in biblical texts. If we wish to break from alienated labor, then we must break completely with the logic of capitalist accumulation and profit, and this is something to which Marx and Jesus would agree. (McLaren, 2015: 54-55)

If Marx and Jesus would agree with the break from alienated labor, why does contemporary revolutionary pedagogy need an additional layer of rituals and beliefs offered by Christianity? More generally, what are the unique emancipatory and educational potentials of Christianity, which cannot be found in traditional non-religious Marxism?

PM: My early work was on the topic of ritual - Schooling as a Ritual Performance: Towards a Political Economy of Educational Symbols and Gestures (McLaren, 1999). Here I followed the work of contemporary symbolic anthropologists - especially Victor Turner in examining rituals as embodied metaphors and in relation to the construction of liminality. I applied these theories in a critical ethnography I undertook at a Catholic middle school in the Azorean community of Toronto. I was able to discern rituals of instruction, of accommodation, and how an anti-structure of resistance was possible under certain conditions. I also identified micro and macro rituals in school settings and how they can be both emancipatory and contribute to the reproduction of hierarchies of power and privilege. I articulated a theory of the teacher as a liminal servant and how the construction of liminality in the classroom can be the seedbed of true creativity, but at the same time a flashpoint for violence. Much of the important work in applied theater, in drama, and performance studies builds on conceptions of ritual. This can be seen in the writings of my late thesis advisor and mentor, Richard Courtney, and is paramount in the work of Augusto Boal - especially in his magisterial volume, Theater of the Oppressed (2008), which was very much influenced by the work of his fellow Brazilian, Paulo Freire.

I was fortunate to participate in a public dialogue with Freire and Boal at the Rose Theater in Omaha, Nebraska, in the early 1990s. It was the first time Freire and Boal had appeared together in such a venue and I was honored to have been a part of this historic event. Symbols have a fecundity that become animated in rituals. They are brought to life, and live inside of us, through play, through rituals, and their elaboration can be seen in the evolution of drama and thought. Symbols are enacted and work synergistically with other symbols; I have termed this process "enfleshment." Here religious and secular symbols can, under specific historical and existential circumstances, hemorrhage into each other and can work in very liberating and also in very dangerous ways. Just think of Francoist Spain and the rituals that linked Catholic symbols to fascism.

According to Miranda (1980), Jesus was the first human being in history to denounce money as the object of idolatry, which centuries later Marx referred to variously as the 
Biblical idols of Baal, Mammon, and Moloch. In fact, when discussing the commodity form of production, he used these terms as much as he did the word "fetish." When Saint Paul talks about the "lust which is idolatry," he is referring to money. Book Three of Capital (Marx, 1981) makes clear that the capitalist mode of production is not the origin of class violence in capitalist society. As Miranda (1980) notes, the class division is created outside the sphere of production, when money becomes god, and it was this god that created the conditions of possibility for the capitalist mode of production. Money as exchange value stands outside production and circulation and yet dominates both. Money represents the autonomous existence of value as the concretization of human labor. It is when money no longer represents commodities, but when commodities represent money, that money becomes a god. Money is the god of all people living under the commodity mode of production and money had already become a god during the time of Jesus. In other words, the accumulation of capital is not enough to automatically create the mode of production we know today as capitalism, because it takes a certain type of historically produced civilization. The transformation of money into capital requires a certain kind of historical circumstance. Today, capitalism still functions as the institutionalization of the worship of Mammon.

Marx does a brilliant job of explaining how money was transformed into a god ruling human beings. Marx reveals how money is both the object and fountainhead of greed, of auri sacra fames, the product of a historically conditioned environment. According to Miranda (1980), Marx perceived the switching of the subject into an object and the transformation of the ends into the means as the centerpiece of the making of a false religion. Marx then applied this "conversion" to economics, to the production of value. Capital finds a way to exchange itself for a commodity that produces more value than the commodity itself - labor power. Capital moves into production through an exchange with labor power, via wage labor, which brings about the separation of the direct producers from the owners of the means of production. Interest-bearing capital is a fetish, a self-expanding value, and it expands its value independently of reproduction, which is a reversal of the relationship between persons and things - all pointing to Marx's anathematization of the worship of money as god. Miranda (2004) points out that at the very central point of his analysis of capital, at the very point where he uncovers the birth of money as a commodity, Marx cites two entire versus from the Apocalypse (Bible, 17:13; 13:17). Marx offers a scientific elaboration of Christ's teaching about the god Mammon.

\section{Jesus was a communist}

PJ: The understanding of money as a god which rules human beings fascinates me. Can we say that it is one of the central points of connection between Christianity and Marxism?

PM: Jesus talked so much about economic sin that it is unfathomable why this is not a central part of the teachings of Christianity. The Lucan part of the Bible explicitly teaches communism (Acts 4:32; 4:34; 2:44; Luke 14:33). Miranda argues that the origin of the communist idea in the history of the West is not to be found in Plato or Marx but rather in the New Testament. The Bible clearly condemns acquired wealth and established wealth and also the means by which this wealth came to be - including various kinds of profit, such as interest on loans, and the expropriation of the produce of the workers' labor by agricultural entrepreneurs (James 5:1-6). Jesus is not against generalized wealth per se, such as the wealth of a people, but against relative or differentiating wealth. Someone 
cannot be rich while another remains poor. Mark 10:25 and Luke 6:20, 6:24, 16:19-31, 1:53 are interpreted by Miranda as arguing that there is no legitimately moral means of acquiring differentiating wealth and that Jesus maintains (Luke 16:29, 16:31) that the same condemnation of wealth can be found in the Old Testament.

Actually, three types of profit are attacked in the scriptures. The Bible itemizes its reproof of profit-taking as occurring through commerce (Ecclus 27:1-2), loans on interest (Exodus 22:24; Leviticus 25:36, 25:37; Deuteronomy 23:19; Ezekiel 18:8, 18:13, 18:17, 22:12; Psalms 15:5; Proverbs 28:8.), and productive activity or the process of production (James $5: 1-6$ ). There is something about the process itself of being able to grow rich that is wicked and unjust (Isaiah 53:9). The acquisition of wealth itself is possible only by exploiting the poor (Job 20:19; Psalm 37). Micha 2-1-2, as well as Isaiah 5:8, focus on how the rich keep acquiring property. Miranda $(1974,1980)$ makes a convincing case that the Bible condemns the exploitation suffered by the poor at the hands of the rich and creates an identity between the rich and the unjust (Isaiah 53:9). Jesus' teachings that enabled the first Christians to base their community on communism can be found in Mark 10:25, Luke 6:20, 24, Matthew 6:24, and Luke 16:19-31.

In fact, Miranda (1980) makes the claim that Jesus was a communist, which can be seen in John 12:6, 13:29, and Luke 8:1-3. Did not Jesus make the renunciation of property a condition for entering into the Kingdom of God? How can God make it possible for a rich person to enter the Kingdom of God? The answer is clearly provided by the Bible. According to Miranda this answer is: By ceasing to be rich (Mark 10:21, 25, 27) and giving away one's wealth to the poor. The scriptural exegesis undertaken by Miranda is, to me, thoroughly persuasive. As a revolutionary Marxist, I am certainly drawn to a number of Miranda's works, Marx and the Bible (1974) and Marx against the Marxists (1980).

PJ: Poverty is a central point of departure for Jesus, Marx, and Paulo Freire. Yet, the answers seem to collide. For Jesus, the poor will inherit the Kingdom of God; for Marx and Freire, the poor should take matters in own hands here and now...

PM: Jesus did not sacralize poverty or preach resignation to it because there will be some extraterrestrial compensation for it in the afterlife. That would be a glib and cynical assessment, and it erases the prophetic nature of such a pronouncement. To say the poor are blessed is not an involuntary justification of the relations and structures of exploitation. The poor are blessed because the coming of the Kingdom in the fullness of history will put an end - in the concrete sociological sense - to their poverty and suffering. Poverty is a form of structural sin that is incompatible with the Kingdom of God. I am not trying to reduce the Gospel to a manual for attaining political consciousness but maintaining that the Gospel has an inherent political dimension. As Gustavo Gutierrez notes,

This conscienticizing of the preaching of the Gospel, which rejects any aseptic presentation of the message, should lead to a profound revision of the pastoral activity of the Church ... the oppressed themselves should be the agents of their own pastoral activity. (1988: 154-155)

Freire was a Christian and sympathetic to Marx, and while I never had a chance to discuss with Paulo the topic of liberation theology, I believe that it would have been a fascinating dialogue. For me, critical consciousness is something that is central to the movement of liberation theology. In the sense that Christians come to recognize not only their preferential option for the poor but, as I would put it, their preferential obligation and commitment to the poor. Critically conscious Christians do not only come to recognize their political 
formation as subjects - their standpoint epistemology - in relation to others, but also gain ontological and ethnical clarity on their role as Christians.

PJ: Christianity seems to have a fairly straightforward attitude to authority: "Let everyone be subject to the governing authorities, for there is no authority except that which God has established. The authorities that exist have been established by God" (Romans 13:1). How does liberation theology deal with this apparent contradiction between biblical messages and critical pedagogy? How can we simultaneously subject to the governing authorities, and engage in revolutionary struggle?

PM: Saint Paul, who was once a Pharisee, campaigned heavily against the legalism that perverted Christianity. Are we not justified by faith and not our adherence to the law? We need to seek to embody our own insight from our own age and not look to entrenched conceptions of the law established in very different historical epochs. We need to constantly renew our understanding of the gospels given the lessons of our own age. People wrestle with many statements made in the Bible that were historically and geopolitically specific to the times.

Liberation theologians focus on the socio-historical captivity of people in the grip of the pretentions of absolute authority and who are the gravest victims of the alienation brought about by capitalism. They seek a reciprocal salvation in their universal and ontological solidarity with the poor and with all of humanity, which is the possibility of our redemption and liberation. This is what critical pedagogy is about. Beginning with biographical experiences of the people, their lived, hermeneutical engagement with others, and interrogating those experiences in the context of those experiences being situated on a larger locus of the capitalist mode of production and what Jesus refers to as "the money of iniquity" (Luke 16:9,11). A subversive praxis of faith challenges the systemization of governing authorities and their closed systems of authority and reprobates all measures of accumulating profit under the vice grip of their authority. Established authority that protects freedom and establishes the conditions of possibility of freedom from necessity and from senseless suffering can certainly be conserved, but in other instances when it works to despoil society it should be challenged by seeking a qualitative transformation of society in the interests of justice and solidarity.

\section{To endure without losing tenderness}

PJ: In Latin America, liberation theology is far from a theory - instead, it is true emancipatory revolutionary praxis. In many cases, actually, practice has clearly pre-dated theory, so our conversation stands on the shoulders of a long radical tradition. What can we learn from the practical examples of liberation theology in Latin America?

PM: I am not sure, Petar, how many of your readers are old enough to remember two earth-trembling and maleficent incidents in El Salvador that occurred in the 1980s during the civil war that broke out during the military dictatorship from 1979 to 1992 . I am referring to the five priests and two women who were murdered outside the Jesuit residence of the Universidad Centroamericana (UCA; founded in 1965), San Salvador, in November 1989. Those murdered were the university rector Ignacio Ellacurí a, an internationally recognized liberation theologian; Segundo Montes, dean of the sociology department and director of the University Institute of Human Rights; Ignacio Martí n Baró, head of the psychology department; theology professors Juan Ramó n Moreno and Amando Ló pez; and Joaquin Ló pez y Ló pez, who headed the Fe y Alegrí a network of schools for the poor. Julia Elba 
Ramos, wife of the caretaker at the UCA and her daughter Celina were also killed (Ellacuria and Sobrino, 1993).

Prior to this horrendous event, in 1980, (the now beatified) Archbishop Ó scar Arnulfo Romero was gunned down saying mass in a small hospital chapel. Before the military regime came to power in 1970s' El Salvador, a number of Jesuits there had begun rethinking and repivoting their work in a concerted attempt to embrace fully the preferential option for the poor that emerged from the conference in Medellí $\mathrm{n}$, Colombia, and to stand shoulderto- shoulder and heart-to-heart with the poor and powerless campesinos. They understood this to mean actively supporting the rights of campesinos and civilian movements promoting social, economic, and political reform.

During the years of the military regime, it was Father Ignacio Ellacurí a, rector at the UCA, who played an influential role during the tumultuous decade of military rule in reframing the university's mission that involved standing in solidarity with the country's impoverished majorities. Ensepulchred in a cemetery of silence and fear, the campesinos were in dire need of government reforms as well as protection from the church, which often stood silent in the face of large-scale torture and mass killings carried out by the heavily armed military regime. Echoing the language of Medellí n, the university's 1979 mission was inextricably linked to the service of the people and, in fact, the mission of the university was in a large sense oriented by the oppressed campesinos themselves (Ellacuria and Sobrino, 1993).

Evidently, the Salvadoran government viewed Father Ignacio Ellacurí a and the UCA as a serious threat to the USA's continued financial and political backing. The USbacked military dictatorship was well aware that if Salvadorean liberation theologians flagged the US Congress about human rights abuses by the government, it might withdraw its crucial financial support, weapons sales, and military training (including methods of torture) in the School of the Americas operated by the USA. The UStrained Atlocatl battalion (who trained the Salvadorean death squads) massacred thousands of unarmed peasants during the dirty war and hundreds were slain in El Mozote alone in 1981. They did not want the Catholic Church interfering in their practices of slaughtering innocent peasants whom they suspected of supporting guerrilla fighters. The government saw this reign of terror as a necessary step in ridding the country of a communist menace that, if not stamped out, would eviscerate the established Salvadorean ruling class.

PJ: Can we say that it was their Christian faith, and the backup of the institution of the Catholic Church, that made resistance so powerful?

PM: Certainly ... but there was another factor at play among the Jesuits that made them so fearless. There was an influence on the Jesuits' work more immediate than Medellí n's teaching of social justice: the example of the martyr Archbishop Ó scar Romero. Shortly after the murders, Major Eric Warren Buckland, a senior US military advisor in El Salvador, testified that his Salvadoran counterpart, Colonel Carlos Armando Avilés Buitrago, chief of psychological operations for the Salvadoran Joint Command, informed him in advance of the planned killing. He later retracted his statement under pressure. Is it so incredible that at least one US official had knowledge of the plot to kill the Jesuits weeks before the event? And did nothing?

In my book, Pedagogy of Insurrection (McLaren, 2015), I wrote a last chapter that I named "Critical rage pedagogy." Here I unleashed a critical rage - using a combination of spoken word and other literary tropes - at the history of human atrocity.

To me, the Kingdom of God is not isolated to, say, a Beethoven symphony, Gregorian chants, the ecstasy of contemplating a mathematical formula, or to a painting by one of the great masters (although I certainly love art and music - not so much mathematics, I will 
confess). For me, the Kingdom of God is found more tangibly on the picket line, in solidarity with the suffering of those who are being brutalized everyday by capitalism by governments, by death squads and by religious edicts that marginalize them and exclude them from their full humanity. The Kingdom of God is found in the act of struggling and sacrificing for the other. Not speaking out for the other, since groups can very often speak for themselves, but speaking alongside and with others, as allies, as friends, as comrades, and as brothers and sisters in Christ.

PJ: Christians in Latin America went through some terrible experiences ...

PM: It is difficult for some people outside of Latin America to comprehend the horrific suffering endured by Catholic priests and nuns in that part of the world during the dirty wars in the 1970s and 1980s, wars involving military dictatorships supported by the USA and death squads trained by the US military. In 1980 four US women, two Maryknoll nuns, an Ursuline nun, and a lay volunteer, were stopped by the military in El Salvador as they traveled from the airport on their way to work with impoverished campesino communities. With encouragement from their commander, a group of National Guardsmen took the women to a cow pasture where they were tortured, raped, and murdered. The rapes and assassinations of Maryknoll nuns, Sister Maura Clarke and Sister Ita Ford, Ursuline Sister Dorothy Kazel, and lay missionary Jean Donovan shocked the world. Sr Ita Ford was targeted specifically by USbacked Salvadoran death squads because she was an outspoken critic in defense of the poor. She wrote the following in a letter to her sister:

You say you don't want anything to happen to me ....I'd prefer it that way myself - but I don't see that we have control over the forces of madness, and if you could choose to enter into other people's suffering, or to love others, you at least have to consent in some way to the possible consequences. Actually what I've learned here is that death is not the worst evil. We look death in the face every day. But the cause of the death is evil. That's what we have to wrestle and fight against. (Dear, 2006)

Many priests and nuns had committed themselves to those who had been victimized by military regimes; they had placed themselves squarely in solidarity with the crucified of history, those whose lives had been devastated by what Leonardo Boff calls the "international sin" of poverty (Boff, 1987: 118) and those who were brutally tortured and "disappeared" by the military regimes. Boff draws our attention to the case of Franciscan Father Ivan Bettencourt, a Colombian diocesan missionary who worked in the Olancho province of Honduras. In 1976, Bettencourt was tortured and killed along with US citizen Father Michael Cypher and 10 campesino organizers after speaking out and organizing against a local land grab in Honduras. This event became known as the "Horcones Massacre." Boff writes that Bettencourt was seized and interrogated, to force him to confess that he was a "Marxist subversive." They cut off his ears and interrogated him. They cut off his nose and interrogated him some more. They cut out his tongue and declared the interrogation at an end. They sliced his body to ribbons. He was still twitching so they machine-gunned him. Finally, they threw him into a well and hid the well under earth and rubble. Father Ivan died defending his brothers and sisters (Boff, 1987: 120).

PJ: These priests and nuns have exhibited remarkable stamina and courage. What can we learn from their stories and experiences?

PM: Some compare the courage and bravery of some of the renegade priests and nuns to that of Che Guevara. Che's motto was "Hay que endurecerse sin perder jamas la ternura" (One must endure [become hard, toughen oneself] without losing tenderness). Some see Che as a 
secular saint, who gave his life for the poor and the suffering in America Latina. Risking death for the cause of the crucified and impoverished of this world gives life meaning, and Che's legacy inspired millions throughout Latin America and the Caribbean. Priests informed by liberation theology saw their mission in light of the social gospel of Jesus Christ, that is, in terms of the political import of the message of Jesus, and bringing about the reign of the Kingdom of God, which included finding collective transcendence in the suffering servant through forgiveness, and through trust and faith in God. We cannot focus on the Christ of personal salvation alone, which is what many evangelicals would have us do. Our individual sins must be reflectively engaged and confronted in light of the gospel message, of course, but we cannot forget the social sins, such as capitalism, which we know is dependent for its survival on surplus value and the exploitation of human labor. Part of what we need to do is to evaluate the events in Jesus' life in light of the socio-historical context of his own life. This demands a social-scientific approach to the gospel message as well as historical-critical approaches. But the social justice aspect of the gospel of Jesus Christ cannot be denied.

I look at the US social order today in terms of the popularity at the moment of Donald Trump; there appears to be a blend of social Darwinism and the racial superiority of white Europeans, nationalism in the form of American exceptionalism and, of course, a religious triumphalism in terms of a God that has given the USA a providential role to play in history. Against this White Jesus of the diseased colonial imagination that secured the privilege of Whites is the Black Jesus, which grasps the perils of racism and imperialism and the prosperity gospel that has grown out of the prosperity gospel of US capitalism. Reggie Williams (2014) has written an interesting book, Bohhoeffer's Black Jesus, that illustrates the impact that the preaching of Adam Clayton Powell Sr, pastor of Harlem's Abyssinian Baptist Church, had on Dietrich Bonhoeffer when he was a Sloane Fellow at Union Theological Seminary in New York for the 1930-1931 academic year. His understanding of the Black experience of suffering, resistance, and transcendence helped him to understand what the Nazis were trying to do to the oppressed peoples of his homeland and also helped him understand the perils of developments within European Christianity.

PJ: What about armed revolutionary violence?

PM: Some scholars and activists cite Frantz Fanon to support acts of violence on the part of revolutionaries, in that Fanon believed violence helps colonized peoples overcome their inferiority complex and gives colonized subjects the necessary courage to continue their struggle. However, Peter Hudis offers a different perspective. In his magisterial book on Fanon, he cites recent studies by Marnia Lazreg and others, based on interviews with Front de Libé ration Nationale (FLN) militants, which maintain "that violence has, at best, an ephemeral 'cleansing' role. More often it dehumanizes and produces long-term distress in its participants" (Hudis, 2015: 121). Throughout the conflicts in Latin America throughout the 1970s and 1980s, priests certainly put their lives on the line to protect and serve the oppressed. Some joined revolutionary battalions to work as chaplains.

\section{The first religious war of the 21st century}

PJ: By standing on the side of the poor, liberation theology has entered the highest spheres of international politics... How does this politics work in practice?

PM: I agree with Noam Chomsky who says that "the U.S. has often been bitterly opposed to Christianity" (cited in Chaudary, 2007) and describes the attacks on liberation 
theology by the US administration as "the first religious war of the 21st century" (cited in Rivage-Seul, 2016). Petar, to back up some of my claims, just read some of the following cables that were released by Wikileaks. In 2013, Daniel Kovalik examined very revealing cables released by Wikileaks that were sent by the US Embassy to the Vatican. For example, in one cable headed "The 'Threat' of Liberation Theology" dated 6 May 2007, the Embassy reveals its unvarnished ideological stance against liberation theology in a message related to the visit of Pope Benedict XVI to Brazil:

Another major contextual issue for the visit is the challenge to the traditional Church played by liberation theology. Pope John Paul (aided by the current pope when he was Cardinal Ratzinger) made major efforts to stamp out this Marxist analysis of class struggle. It had come to be promoted by a significant number of Catholic clergy and lay people, who in a political compromise sometimes sanctioned violence "on behalf of the people." The more orthodox form of liberation theology that sided with the poor and oppressed had undergone a reductionist reading that the Vatican sought to correct. To a large extent, Pope John Paul II beat down "liberation theology", but in the past few years, it has seen a resurgence in various parts of Latin America. (Kovalik, 2013)

Another cable from the US Embassy to the Vatican, on 14 January 2008, included a summary of Pope Benedict's current views on Liberation Theology:

\begin{abstract}
Also important - and disturbing - to the Holy See is the resilience of Latin American liberation theology. During his time as the powerful Prefect of the Congregation for the Doctrine of the Faith in the 1980s and 1990s, the then Cardinal Joseph Ratzinger opposed liberation theology for its overt sympathy for revolutionary movements. Some of the supporters of this theology - including former clerics - now occupy prominent political positions in countries like Bolivia and Paraguay, a phenomenon that one commentator has described as the secular reincarnation of liberation theology. For the Holy See, the Church Magisterium (the teachings of the Catholic Church) on social issues already advocates strongly for the rights of the underprivileged. This advocacy, often described as the Church's "preferential option for the poor", should not include clerics assuming high level governmental positions or running for office. In calling for a reduction of domestic tensions in Latin America, the Holy See hopes to prevent a climate fertile for activist, progressive clerics to coalesce with populist, authoritarian governments. (Kovalik, 2013)
\end{abstract}

What follows is an excerpt from a cable from 27 September 2005 released by the US Embassy in San Salvador, entitled, "El Salvador: The Declining Influence of The Roman Catholic Church." This cable states that

In 1977, former Archbishop Oscar Arnulfo Romero adopted an outspoken stance in favor of "liberation theology" that alienated many of the church's most influential members. Archbishop Arturo Rivera y Damas followed Romero's example during his 1983-1994 tenure. Much changed in the years following the 1992 Peace Accords, which ended repression and violence on the part of government forces and guerrillas. With the selection of Fernando Saenz Lacalle as Archbishop of San Salvador in 1995, the Catholic Church entered a new era during which it withdrew its support for "liberation theology"; SaenzLacalle has placed a renewed emphasis on individual salvation and morality. However, an underlying division still exists within the Salvadoran Catholic Church vis-vis such political issues. (Kovalik, 2013) 
The Embassy later explains that "[t]he Salvadoran Catholic Church has in effect been 'reRomanized'...." (Kovalik, 2013). Kovalik comments on this cable as follows:

... what is left unspoken is that it was the murder of good people like Archbishop Romero that led to the Church "re-Romanizing" - a term with a double meaning, for it can properly mean that the Church is again in line with the Vatican in Rome (the intended meaning), but also that it has returned to the pro-Empire stance the Church has maintained (with limited interruption after the second Vatican Council in 1962) since 324 A.D. In other words, mission accomplished for both the Vatican and the U.S. (Kovalik, 2013)

Another cable from San Salvador, dated 24 June 2008, attempts its own historical overview of the FMLN (Frente Farabundo Martí para la Liberació n Nacional or Farabundo Martí National Liberation). The Embassy offers a highly distorted picture when it writes:

During the 12 year Salvadoran civil war (1980-92), the FMLN attempted to overthrow the government utilizing a strategy that included armed struggle, terrorism, socialist/communist political indoctrination. The liberation theology movement within the Catholic Church and labor unions largely supported these efforts. The group received monetary support and arms from the Soviet Bloc and Cuba. (Kovalik, 2013)

Here the liberation theology movement is unjustly painted as supporting terrorism with the clandestine support from the Soviet Union and Cuba. Absent from these overblown claims is the fact that the US-backed military and paramilitary death squads in El Salvador committed horrendous acts of terrorism against the civilian population that has been clearly documented. Furthermore, the leading proponents of the liberation theology movement, such as Archbishop Romero, condemned violence from both sides of the conflict. The release of these confidential cables from the US Embassy by Wikileaks, as reported by Daniel Kovalik, reveals the staggering extent of the current war against liberation theology by the US State Department. Given the history of coordinated US attacks on liberation theology, it is difficult to disagree with Noam Chomsky when he states that,

... the U.S. Army helped defeat liberation theology, which was a dominant force, and it was an enemy for the same reason that secular nationalism in the Arab world was an enemy - it was working for the poor. This is the same reason why Hamas and Hezbollah are enemies: they are working for the poor. It doesn't matter if they are Catholic or Muslim or anything else; that is intolerable. The Church of Latin America had undertaken "the preferential option for the poor." They committed the crime of going back to the Gospels. The contents of the Gospels are mostly suppressed (in the U.S.); they are a radical pacifist collection of documents. It was turned into the religion of the rich by the Emperor Constantine, who eviscerated its content. If anyone dares to go back to the Gospels, they become the enemy, which is what liberation theology was doing. (Cited in Chaudary, 2007)

PJ: Speaking with and speaking together with the poor is one of the central messages of both liberation theology and revolutionary critical pedagogy. In the capitalist world, however, the very act of speaking is privileged - so many people are excluded from full participation in economic, political, and other spheres...

PM: William Robinson (2004, 2014, 2016a, 2016b) has reported that approximately one third of humanity is locked out of productive participation in the capitalist economy. We can find a larger number of this group in Latin America. There has been a dramatic shift in the 
USA and other countries since the end of World War II from an admirable concern with social welfare to a preoccupation with social control and creating a national security state. There is a pronounced fear now among the ruling elite that outraged workers will rise up and protest living in what is fast becoming planet slum. Robinson notes that the role of the state in creating social cohesion through the accumulation of capital is fracturing as a result of the crisis of capitalist over-accumulation. Consequently, the state is fast losing its "legitimatizing" function, and we can see this now in the election cycle here in the USA when outsiders to the government - such as Trump - are rising up and urging people to demonize the surplus population through a logic overlain with hate and violence.

PJ: More often than not, the concept of surplus population (which is a terrible phrase in its own right) is linked to changes in the structure of employment caused by new technologies. What is the role of technology in this context?

PM: Not only is capitalism retooling itself, but also hiring practices for college graduates are likely to shift in an ominous direction. It likely will not be too long before Human Resource Professionals hired by your potential employer will determine your fitness for employment, extensions of credit, or admission to certain schools, based on computerized personality screening and data collection. For example, personality tests designed by computer programs that capture and evaluate your "Likes" on Facebook and other digital markers could follow you throughout your career or perhaps even "haunt" you. Wu Youyou, Michael Kosinski, Thore Graepel, and David Stillwell (Kosinski et al., 2013; Youyou et al., 2015) of Cambridge University's Department of Psychology and the Stanford University Department of Computer Science are developing a computer model of psychological assessment and personality profiling that assesses their subjects' personalities based on their "generic digital footprint" and employs what they call a "fivefactor model" consisting of a standardized set of personality traits that measure Extraversion, Agreeableness, Conscientiousness, Neuroticism (sometimes named by its polar opposite, Emotional Stability), and Openness to Experience.

Computerized programs like this one - which the researchers argue are better equipped to assess personality traits than living and breathing human beings - are very likely to be utilized by future employers. This type of research goes much further than the "predictive analytics" used by Facebook and other social media sites. Certain algorithms or websites that you visit will determine that you are unsuited for jobs that you want. How has technology turned into such a companion of the security state? Freire maintained that "education for liberation does not merely free students from blackboards just to offer them projectors" (1973: 4). Computer science here has become completely domesticating. They are the result of the contradictions within their own power structures, serving capital by instrumentalizing our personalities and subjective agency.

Is this so surprising today, when public education is being turned into a series of investment opportunities? We see it in the retooling of colleges in order to serve better financial and military-industrial interests, in the overuse and exploitation of contingent faculty, in the growth of for-profit degree-granting institutions, in rising tuition and, not to mention, the assault on critical citizenship in favor of consumer citizenship. There are many struggles to take up in the making of the Kingdom of God.

PJ: Speaking of profiling technologies, computer science has become indeed domesticating. What is the role of social media in these developments?

PM: I worry, Petar, about social media. Yes, I can see the possibilities surrounding information sharing and communication across nations and impacting geopolitical arenas 
for the common good. But there is a dark side and it is everywhere. Google is a megacorporation, part of the social brain that masks itself as an innocent and innovative Silicon Valley offspring, spawned by computer and technology nerds sporting bow-ties and pocket protectors and looking for ways of bringing people together to share information. It pretends that it is autonomous from the imperatives and foreign policy decisions of the state and not in collusion with the military industrial complex, but in fact it is insinuated very seamlessly into the whole machinery of rule and hegemony of the ruling class, what Gramsci called the integral state. The patricians, proconsuls, and nomenclature of Google have become the custodians of secret dealings they have had with the US State Department. Google shares the same political DNA with the National Security Agency (NSA), the CIA, and the Pentagon. Google is a sentinel for US foreign policy, and charioteers for US imperialism. Their apparatchiks come from all the dark catacombs of the national security state.

\section{Towards a global ethics of solidarity}

PJ: I am fascinated by your stories and examples from South America... and I deeply sympathize with the message of liberation theology. Yet, Peter, I come from a radically different context - Eastern Europe - where various Christian denominations are traditionally on the side of the right. In Croatia, it is the Catholic Church that campaigns against gay marriages, and the right to abortion... It is just last week that they had another rally. When you see those people protesting to penalize anything that deviates from their own vision of the social norm, it is hard to feel empowerment and emancipation... In this part of the world, unsurprisingly, lefties of all shapes and colors are very cautious towards religion. How do you go about such contradictions between liberation theology and our social reality?

PM: I am not surprised, Petar, about the Church in Croatia. We have a strong right-wing Catholic movement here in the USA that is decidedly against Pope Francis and liberation theology. Francis is not a proponent of liberation theology but of what developed in his native Argentina as teologia del pueblo, or theology of the people. It begins with the experiences of the oppression of people in the face of neoliberal capitalism and corporate globalization. The Catholic Church is not monolithic. There are fundamental ideological differences within the Church. I think that Pope Francis's experiences with the military dictatorship and his contact with fellow Jesuits who did support liberation theology made a powerful impact on him and helped him to adopt certain perspectives from liberation theology, such as a critique of global capitalism.

Liberation theologians openly contest certain positions taken by the established Church, just as Pope Francis does. Francis is more moderate in many of his views than many of the prominent exponents of liberation theology. Nevertheless, he has taken strong positions against global capitalism and environmental destruction that I welcome and applaud. Do we obscure the spiritual nature of the gospel by calling for more than just an identification with the poor but rather a robust confrontation with the rich and powerful? Do we administer to the poor without asking why they are poor? Here we need to recall the words of Brazil's Dom Hé lder Câ mara, whom Paulo Freire very much admired: "When I give food to the poor, they call me a saint; when I ask why the poor have no food, they call me a communist" (Câ mara, 2009).

In 1965, as the famous Vatican II Council was coming to a close, Hé lder Câ mara led 40 bishops late at night into the Catacombs of Domitillia outside of Rome. After celebrating 
the Eucharist, they signed a document under the title of the Pact of the Catacombs, challenging themselves and others to live lives of evangelical poverty and to dedicate themselves to serving the two-thirds of humanity who live in poverty and deprivation. There are certainly ideological differences within the Church and in some countries - such as Croatia and Poland - the right-wing factions of the Church hold sway.

PJ: Your answer reflects political tensions between the left-wing and the right-wing political factions within the church. However, I am conflicted about much more "mundane" things, and the ones that the whole Catholic Church seems to agree about. Examples include the explicit position of the global Catholic Church against using condoms, against abortion, and against gay rights. In some areas of Africa, for instance, AIDS kills significant parts of the population, while the official church position - articulated, amongst others, by Pope Benedict XVI - claims that the HIV epidemic is "a tragedy that cannot be overcome by money alone, that cannot be overcome through the distribution of condoms, which even aggravates the problems" (cited in Butt, 2009). How do you go about such teachings and their consequences? More generally, how do you reconcile them with the message of liberation and emancipation?

PM: Yes, there are positions taken by the Church hierarchy that are firmly established and to which I remain in trenchant disagreement. And yes, they involve many of the same "mundane" issues to which you allude, but I do not think they are so much mundane as pervasive and impacting everyday life. I remember a Paulist father once telling me that I should never lose my critical approach to questions of dogma and faith. We want you to be a thinking Catholic, he told me. I do not believe the guardians of the faith would be very pleased with revolutionary priests accompanying guerilla armies as chaplains, such as Camilo Torres of Colombia or Gaspar Garcia Laviana of Spain. Yet I see their actions as heroic. We must act according to our conscience, in deep reflection and contemplation.

Going back to powerful analysis by Noam Chomsky, we should also consider the conditions in which these positions are being developed. Speaking about the US context, Chomsky says:

There is a correlation, common in other parts of the world as well. When life is not offering expected benefits, people commonly turn to some means of support from religion. Furthermore, there is a lot of cynicism. It was recognized by party managers of both parties (Republicans and Democrats) that if they can throw some red meat to religious fundamentalist constituencies, like say we are against gay rights, they can pick up votes. In fact, maybe a third of the electorate - if you cater to elements of the religious right in ways that the business world, the real constituency, doesn't care that much about. (Cited in Chaudary, 2007)

These messages of the Church hierarchy are being heavily instrumentalized by politicians, who gain cheap votes over issues such as abortion or gay rights.

PJ: And what about spiritual aspects of these messages?

PM: I very much appreciate indigenous traditions and what they bring to discussions of spirituality. My approach is broadly ecumenical and includes Buddha, Mohammed, Krishna, and the Great Spirit of the native American traditions. Human welfare and wellbeing should be placed above the law. Condemnation of homosexuality in the Bible is very different from the way progressive individuals view homosexuality today, which is grounded in post-Enlightenment science (Rivage-Seul, 2008). It seems to some exegetes that what was forbidden was not homosexuality itself but heterosexuals engaged in homosexual acts (Rivage-Seul, 2008). Jesus himself was silent on the question of homosexuality. I agree 
with Boff when he writes that "The paradox of the cross is incomprehensible both to formal and to dialectical reason" (1987: 135), but this should not be used as a pretext for blind obedience to law. What is concealed in this mystery will be revealed through struggle - that is, through praxis - and not simply reflection or adherence to laws with which we disagree. Boff writes that "the incarnation is already present at the beginning of the universe" (1997: 178) and "the universe culminates in each individual in the form of consciousness" (1997: 121). He writes that "all energies and morphogenetic fields have acted synergistically so that each one might be born and be that singular and unique person that he or she is" and so it seems to me that we each have something very worthwhile to contribute to the debate through a cultivation of critical consciousness.

We have, all of us, been here since the beginning of the universe and are made out of star dust. And it is the guiding principles of the universe that brought us here, and that has resulted in the potential for our self-actualization, and that has taken 15 billion years of evolutionary processes. We had better start to listen to indigenous sages who have understood this far better than we Euro-Americans here in Babylon. We need to abandon our anthropocentric and mimetic desires and subject ourselves to a global ethics of solidarity, compassion, and fellowship so that our outer ecologies can be brought into cosmogenetic harmony with our ecology of the mind and spirit. And here we bring our maieutic processes of pedagogy into dialogue with a Freirean approach to conscientization. In other words, we bring together history, mind, and spirit. I reject a turgid monotheism that would cleave us from spiritual traditions that predate Christianity. In short, I would say that we must act in accordance with our own conscience.

\section{Between the material and the spiritual}

PJ: Are there any theoretical and/or practical dissonances between Marxism and Christianity in your theory? If there are, how do you go about them?

PM: While some might argue that traditional non-religious Marxism is not as equipped as theological traditions to engage fundamental questions pertaining to the hermeneutics of spirituality, there are numerous Marxist theorists who have written profoundly about issues of the spirit - here, I am thinking of Ernst Bloch, Walter Benjamin, and Erich Fromm, just to name a few. I think Marxism does address issues of the human spirit, but what interests me, in particular, is an engagement with a tradition that deals with a triune god. Of course, liberation theology comes in many forms: Chicano liberation theology; Latinx liberation theology; Native American liberation theology; African American liberation theology. Therefore, I do not want to limit liberation theology to the political theology that comes out of Europe, or to the Latin American liberation theology that is primarily Catholic and pastoral.

I work as a Marxist materialist but I believe there is a world beyond physicalism. That is a world of hope. Hope is conjugated in opposition to injustice and gestated in the struggle of humanity against inhumanity. Rubem Alves (cited in Boff, 1987: 124) writes of hope as follows:

Hope is the presentiment that the imagination is more real, and reality less real, than we had thought. It is the sensation that the last word does not belong to the brutality of facts with their oppression and repression. It is the suspicion that reality is far more complex than realism would have us believe, that the frontiers of the possible are not determined by the limits of the present, 
and that, miraculously and surprisingly, life is readying the creative event that will open the way to freedom and resurrection...

Hope does not deliver us from suffering. But hope, I believe, can deliver us from the fear of suffering. It does this by giving us the courage to believe that we are not fated to live in misery, that light does shine through the cracks of the day-to-day sepulcher in which we find ourselves, in this cold and damp undercroft, in this darkness of inevitability.

PJ: What are the more general challenges that you encountered on the path of reconciliation between the spiritual and the scientific?

PM: Writing Pedagogy of Insurrection (McLaren, 2015) brought me face-to-face with questions that by no means have I worked out to my satisfaction. What I can say is that I certainly do not believe that knowledge is simply produced by the rational permutations of the brain. I do believe that it is possible to posit a divine consciousness that pervades our existence. I will note parenthetically or in passing only that there are some interesting speculative developments in theology centered around some ideas in quantum mechanics where field-based waves are seen as producing the hardware of the universe and the entities of the space-time domain, while the scalar or non-vectorial waves produce information without carrying energy and act like the software of the universe. The information that interconnects entities throughout space-time includes upward and downward causation, which helps to explain why the past is always present. Here, a definition of God might include the potentials of the universe for its self-creation, which might involve, for instance, tuning the universe to the evolution of complexity.

Here, Teillhard de Chardin's work (1959, 1964, 1965, 1966a, 1966b, 1968) becomes even more interesting and relevant. In this view, God can influence the course of revolution without interfering with the laws of nature. Some physicists argue that the original presence of this information can be ascribed to a transcendental creative act where the growth and development of this information is considered immanent. I am not wellversed enough in physics to evaluate this speculative argument. However, there are several practice-oriented codes of moral behavior that have been generated out of this work by Ervin Laszlo (2014), who has come up with a minimum moral code (live so that others can live) and a maximum moral code (act so as to further the evolution of a humanly favorable dynamic equilibrium in the biosphere). I would modify this, however, to include non-human animals. To me, holistic and local domains of consciousness are interdependent and material and mental domains are bidirectional so that when unconscious contents become conscious, this transition could possibly alter the unconscious memories left behind.

PJ: What are the ontological implications of this? Are you saying that something can exist beyond matter?

PM: Let us just say that I remain skeptical of the physicalist interpretation of reality that denies certain experiences that are connected to the transphysical. The idea of a nonemergent irreducible mind within a psychophysical world is worth considering in my estimation and this, of course, would take us to the Renaissance Neoplatonists and also to Bergson, Emerson, Schopenhauer, and Kant. Here I would need a broader theological framework that many Marxist traditions are not equipped to handle. An expanded view of mind is not, in my view, antithetical to Marxism. Consciousness is not a mere epiphenomenon of the material brain. We need new visionary taxonomies to help us understand anomalous experiences that cannot be explained by a physicalist interpretation. Does that mean that I believe the cosmos was created by an upwelling of 
the mind of God? Does that mean that Joseph of Copertino could actually fly? I do not spend a lot of time pondering these questions. I am more concerned with living with clarity and in preferential solidarity with those who are victims of the scandal of poverty and who belong to despised racial and ethnic groups and exploited social classes.

I am not here trying to push a neo-Platonist line of reasoning - yet, I remain open to various explanations of how the cosmos came into being. In my political work, I remain very much a historical materialist. I think this is the best approach for understanding the dialectical relationship between capitalism and labor (and materialism and idealism, for that matter) in the larger struggle for a socialist future. While I do not deny the material world, I am very interested in the nature of consciousness, and I would not in the least be surprised if consciousness exists independently of the brain, with the brain serving as a type of filtering device to gain access to the deep layers of the psyche. The brain here is conceived as a system that constrains the supraliminal conscious expression of normally inaccessible subliminal contents. And here I am echoing the work of FWH Myers and William James and the work of contemporary researcher Edward Kelly (Kelly et al., 2007, 2015) and the notions of the subliminal self and the supraliminal self.

Now all of this interest I have in religious experiences, the nature of consciousness, etc., is mostly just engaging in thought games. One day perhaps I will be able to make more nuanced reflections about the nature of the cosmos, our role on this earth, and the place that faith plays in our lives. Yes, I do return over and over again to certain questions, figures, and memories. I return to questions "on the ground," questions that involve what Michelle Alexander calls "the new Jim Crow." The massive discrimination policies directed towards people of color in the areas of education, employment, public benefits; the mass incarceration of African-Americans and Latinos through the war on drugs and anti-crime policies; a criminal justice system responsible for creating and reproducing the racial hierarchy in the USA; or what could be called the American Caste System - the privatization of prisons ensuring large incarceration rates of prisoners of color.

PJ: I am interested in this dialectic between the material and the spiritual, the real and the mystical, the human and the divine ... and I guess that, in order to remain living in this world and with this world, one needs to find a certain balance between those radically different views to our earthly existence. How do you go about obvious and inherent differences and contradictions contained in these dichotomies? What keeps your materialist critique from plunging into pure mystics; what keeps your spiritual worldview attached to the material world?

PM: As a dissident educator whose resistance has been forged on picket lines, on marches, amidst military sweeps of unruly neighborhoods, in libraries, churches, seminar rooms, museums, revolutionary institutes, classrooms, clandestine meeting places, and public squares, I have always felt that I live in the interstices of internal contradictions, in the hinterlands of the unexcluded third, in the fructifying poetry of chaos and the absurdity of being, in the pluriverse of values in which we are pushed to make choices, where being and nonbeing interpenetrate amidst the explosion of metaphors and magical incantations, where everything transforms into something else, where whispers from primeval groves of evergreens turn into thunderclaps, where an infant's sigh turns into the oratory of a politician, where journeys begin at their destinations, where coherence mingles amicably with ambiguity.

As a teenager I was very interested in Theosophy, eastern religions, the Christian mystics, the desert fathers, and the lives of saints. I do not pay much attention in my recent work to 
Bruno Giordano, Marcion, Valentinus, Simon Magus, Appelles, or the Christological or ecclesial Gnosticism or Docetism that is associated with their teachings, which is not to say they do not offer some interesting points of debate. In this respect, however, I follow Jon Sobrino in defending the living, breathing, bleeding, and pulsating flesh of the man we call the Christ, the ecce homo. Of course I am inspired by the life of the saints and martyrs such as Saint Maximilian Kolbe, patron saint of drug addicts and political prisoners, whose prison cell I visited last year in Auschwitz. In my own work I have found it important to uphold the humanity of Christ without de-emphasizing Christ's divinity, and for me the humanity of Christ is best embodied historically in Jesus' birth, death, and resurrection, and all that occurred during his dispensation among us. Here I am emphasizing Christ walking among us, among the victims of the brutality of structural sin, among the sick, the homeless, the diseased, the despised, those who despair of life, those whose pilloried flesh stand as a testament to the injustice meted out by the powerful to the most vulnerable. In other words, I try to concern myself with the story or narrative of Christ, his narrative being that in no way denies Christ's divinity.

But we can very easily become lost in the unreality, the mystical body of Christ, or the Church, for that matter. Our humanness, our soft flesh, and breakable bones is what Sobrino (2001: 276) refers to as "the condition of possibility of salvation" through the "homo verus" (Sobrino, 2001: 278), that is, through Christ's constitutive relationship with God and history, and history and transcendence. We need, as Sobrino argues, a truly humanized Christ, not simply a demythified Christ produced in the libraries and sanctuaries of Rome by theologians of various ecclesiastical stripes. Let us not get too tangled up in what is real in Christ and what is divine, for what is truly human is that which can bring us victory over inhumanity, over the anti-Kingdom, through speaking truth to the demonic power ensepulchred in the vaults of alienation wrought by capitalism and its attendant antagonisms. So, for me, developing a philosophy of praxis means learning how to walk in history, as both the subject and the object of our human story, lacing up our thirsty boots and refreshing our parched spirit as we journey alongside the victims of social sin, moving from the historical to the transcendent through faith.

\section{The socialist Kingdom of God}

PJ: An important aspect of Christian mystic - and the one you earlier identified as one of the main intersections between Christianity and Marxism - is the eschatological aspect of history. For Christians, this eschaton is the (arrival of) the Kingdom of God; for Marx and Engels, it is utopian socialism predicted as early as in the Communist Manifesto (Marx and Engels, 1848). Can you elaborate upon this eschaton a little deeper? What, for you, is the Kingdom of God?

PM: We have to honor the victims, speak to their lives of suffering in their theological reality. As Sobrino notes, the crucified peoples of this earth must not be remembered as some historical add-ons to our Sunday sermons but as those who were victims of the anti-Kingdom. After all, the anti-Kingdom is the Kingdom of Capital, of Wall Street and the world of value production (i.e. monetized wealth), of profit, of the exploitation and alienation of human labor, of private ownership of the means of production, of the market mechanism that forces capitalists (regardless of whether or not they are good people) to exploit workers, of the emergent transnational capital consolidated in a global capitalist historic bloc and the pillage zones of America Latina, and of the deregulated, informalized, and de-unionized capital-labor relation and the worldwide subordination of labor. 
But here I need to emphasize something Sobrino (2001) has discussed at length in his many important writings. While we focus on the divine in Christ, we have forgotten the Kingdom of God of which Christ speaks. So when we identify as Catholics, why have we forgotten the primacy of creating the Kingdom of God and bringing it forth as Christ exhorted us to do? In my view, it is because our entire system operates as the antiKingdom. Christianity itself is undergirded by the imperatives of the anti-Kingdom in that it has attached itself to the imperatives of capitalism. To create the Kingdom of God means seeking the creation of a social universe outside of value production, or the production of profit for the rich. Creating the Kingdom of God means liberating the poor and this means ending the brutal war against the poor unleashed by the deregulation of the market. It means challenging the anti-Kingdom that stands against immigrants seeking a better life, against migrant workers, against refugees, and the intergenerationally reproduced barrios of planet slum. We focus instead on eternal life, on gnostic mysteries, and distance ourselves from the Kingdom of God with reality TV and the hundreds of TV channels we have at our disposal. We confuse the drive to increase material wealth with the drive to produce value, or create endless profits that can be expanded indefinitely.

In our forays into the hinterlands of mysticism, we cannot forget that the Kingdom of God is, in Sobrino's terms, a "type of historical-social-collective reality" (2001: 334) and not, as the old union song has it, a "pie in the sky when you die." The Kingdom of God is not some metaphor for an unearthly paradise, some ecclesiastical makeover of the earth in terms of the divine Christ or such that the holy and apostolic church becomes the prime sign or marker of the Kingdom. Clearly, for me, the Kingdom of God is not some place where wellheeled and aristocratic-looking souls lounge about in togas and golden wreaths. For me, the Kingdom of God is more likely found on the picket lines, in the temple cleared of the moneylenders, in a world where the rich no longer dominate, a world where death squads do not murder peasants with impunity, and where poor tenants do not confront racist landlords and developers do not build themselves towers in glorious homage to their wealth and power while others are forced to sleep under bridges.

PJ: Please explore some practical aspects of the eschaton. What are the main obstacles for its arrival? Where should we seek novel patterns of revolution for social justice?

PM: We have failed to reason dialectically, and to construct in our daily lives a philosophy of praxis grounded in a Christian Marxist humanism. Consequently, we are suffocating - here in the USA - in the furious winds of this Armageddon culture filled with doomsday pronouncements and with extreme right-wing conspiracy theories about a cabal of international bankers taking over the world and leaving the USA in the wake of the corporate globalist elite. This so-called cabal of corporate globalists has left poor whites barricaded in their crumbling towns and inner cities to be monitored by black helicopters from the United Nations and devoured by groups such as Black Lives Matter activists, immigrants of all stripes, Muslims, feminists, West Coast climate activists, and those who run the entertainment industry in the heart of Sodom. The Avenging Angel of the God of Money is a transnational capitalist billionaire and media personality who judges the entire world through the eyes of a circus ringmaster and a beauty pageant judge. Unbeknownst to the working classes, this is exactly the type of savior who will hurt their ranks the most. What has hurt them the most is not the elite political class who run the government, but the economic system that the government has been set up to defend.

The Kingdom of God is not suddenly going to appear after the apocalypse that is haunting us retroactively from the future has eliminated evil once and for all. 
The Kingdom of God is not designed to save capitalism but to replace it with a more just and humane system that is not driven by the profit motive. The eschaton is now, and it is the struggle for social justice that makes it immanent. We are not talking about the struggle shouldered by liberals singing their sundry progressive platitudes all the way to the offices of their investment bankers. The struggle for social justice stipulates that we come together and figure out how to create a social universe outside of capitalist value production, where the profit motive is eliminated. Education should play a significant role in this struggle, but it does not. This is why I have been trying to advance critical pedagogy as a transnational social movement to bring progressive educators together to face the problems of contemporary capitalism and to seek alternatives, because we are facing a capitalism that has continuously played a role in genocide, ecocide, and epistemicide, the latter referring to the abolition of ecologies of knowing of indigenous peoples.

The international law introduced by the 1948 United Nations Convention on Genocide makes it abundantly clear that the USA systematically sought the complete expiration of native Americans amounting to genocide against first nations peoples. Have we not recently destroyed the nation of Iraq? Have we not tortured and traumatized its population? Have we not soaked its gene pool in depleted uranium and ensured birth defects for generations to come? Has not the USA intervened militarily in approximately 50 countries since World War II? We have a long revolution ahead of us to stop such a global system of war and aggression and to replace capitalism with a socialist alternative.

The pattern of revolution for social justice - for socialism - will not be a straight line but will always be up and down, a path of walking through darkness and light, fighting inside the belly of the beast until, like Jonah, we are spit out onto the shore of hope. Is Jonah inside the belly of the whale not a story of entering the darkness, of being betrayed, of being the scapegoat, of being victimized by power, in order, finally, to land on the shore where we can be regain our breath, where we can be bathed in the light of truth? Is not the story of Jonah inside the whale, really an anti-sign, another way of rendering the doctrine of the cross? Is this not what is called "the paschal mystery"? As Rohr (2016) reminds us, mystery is not something that is impossible to understand, it is "something that you can endlessly understand," since at no point can you say, "I've got it!" Sometimes the descent is so great, so steep, that there seems no hope, just a vortex of horror and turmoil. It seems impossible at times to fathom how humanity can survive the horror of existence, especially during times of war, of economic catastrophe, of existential desperation and despair. How can God be found in this darkness? This truly is the paschal mystery.

PJ: Can you link this paschal mystery, the Christian eschaton described as the Kingdom of God, to Marx's prophecy of the future socialist society?

PM: I do see socialism as fitting in with the Kingdom of God announced by Jesus. Socialists in the past have sometimes made such a connection. Take the case of Helen Macfarlane. In 1850, Scottish governess, Helen MacFarlane, wrote polemical treatises supporting the Chartist movement. She was the first person to translate Hegel's philosophical writings into English and the first person to translate The Communist Manifesto into English. The Chartists were the first working-class movement to fight the British establishment in order to secure rights for the working class. For a time, MacFarlane supported Chartist leader Julian Harney in rebuilding the movement from a socialist and international perspective and refused to moderate the movement to win over the radical liberals. She allied herself with Marx and Engels and took on literary giants such a Thomas Carlyle and Charles Dickens. She interpreted Hegel as a humanist pantheist and she 
defined pantheism in humanistic terms. Her work reflects the Hegelian pantheism of David Strauss and her engagement with Marx and Engels helped her to radicalize Strauss's critical Hegelianism. For Hegel, the importance of the gospels was their symbolic content. For David Strauss, what was important about the gospels was their historicity - as myths that contained the Messianic desires of the early Christian communities (Black, 2014: xvii).

Feuerbach believed that theological knowledge was subjective and that the final criterion for the truth was to be found in the senses. Here the ego remains passive and determined by objective reality. For Marx, truth was found through historical praxis, through the negation of the negation. What is interesting about Macfarlane was her ability to merge the ideas of socialism, left Hegelianism, and Marxism with the teachings of Jesus and in doing so spiritualize the struggle for social justice. In 1850 she wrote:

We Socialist-democrats are the soldiers of a holy cause; we are the exponents of a sublime idea; we are the apostles of the sacred religion of universal humanity. We have sworn by the God who "made of one blood all nations of the Earth", that we will not pause till we have finished the great work - begun by the Nazarean - of man's redemption from the social miseries which destroy body and soul. (Macfarlane in Black, 2014: 22)

PJ: If the Kingdom of God is a "type of historical-social-collective reality" (Sobrino, 2001: 334), why should we not just stick to Marx and Engels' utopian socialism? Why, in this context, do we need a God?

PM: As a species on the verge of extinction, we have an ongoing obligation today to commit ourselves to build a network amongst the working class, the peasantry, and the urban cognitariat and precariat in order to break down the immutable hierarchies of power and privilege concomitant with the workings of capitalist society. In our struggle to achieve this, God will be revealed. As Miranda writes: "Only in a world of justice will God be" (1977: 45). The revolution therefore depends not on the man himself or the woman herself or on the collectivity (which would be merely expanded egoism), but on the Other. Providing for each according to his or her needs presupposes caring for people simply because they exist and are God's children. The social relations of capitalist exploitation can force us to yield but they cannot oblige us to obey. God is the moral imperative itself, the imperative to struggle against injustice and innocent suffering. God's presence in history, the true revelatory intervention of the God of the Bible in human history, occurs when we take up the struggle for social justice.

It is interesting to note that Marx and Engels entered an organization in 1872 that was founded by Wilhelm Weitling, the founder of German communism. Weitling's organization was based on a communism grounded entirely in the gospel, as can be seen in his 1845 book, The Gospel of a Poor Sinner (Miranda, 1980). Marx was a great admirer of the Peasants' War organized and directed by Thomas Munzer in the 16th century. This was, in effect, the first anti-capitalist revolution. Munzer argued that the Kingdom of God is a condition of society without class differences, without private property, and without state powers opposed to the members of society.

\section{The God of the rich and the God of the poor}

PJ: Your work is a masterpiece of dialectics ...Where issues pertaining to ontology and epistemology pour into issues pertaining to politics and emancipation, there still is - even if only historically constructed - some sort of "division of work" between the different 
approaches and disciplines. What is the main strength of Marxism in the context of liberation theology?

PM: I return to the basic issues of the violence of capitalism, colonization, genocide, and the underlying epistemicide, which can be best understood as the destruction of epistemologies, ways of knowing, and ecologies of the mind of indigenous peoples throughout the world. Now for some proponents of liberation theology, communism as Marx envisioned is normative in the message of Jesus. And I have faith that the Kingdom of God will overcome the world of suffering precisely because I have faith in the people, the workers, the masses to defeat capital and bring about a more loving and human system for providing for the material needs of humanity. Terry Eagleton writes:

I have argued already that reason alone can face down a barbarous irrationalism, but that to do so it must draw upon forces and sources of faith which run deeper than itself, and which can therefore bear and unsettling resemblance to the very irrationalism one is seeking to repel. (Eagleton, 2009: 161)

It is worth remembering, as Eagleton notes, "The Christian way of indicating that faith is not in the end a question of choice is the notion of grace. Like the world itself from a Christian viewpoint, faith is a gift" (2009: 138). Of course, this does not mean we cease examining our faith with evidence from the phenomenal world. Eagleton sees the great struggle today as one in which culture is pitted against civilization. He notes that "culture ... is too much a matter of affirming what you are or have been, rather than what you might become" (2009: 165). And as for religion? Eagleton writes:

What we know as Christendom saw itself as a unity of culture and civilization. If religion has proved far and away the most powerful, tenacious, universal symbolic form humanity has yet to come up with, it is partly on this account. What other symbolic form has managed to forge such direct links between the most absolute and universal of truths and the everyday practices of countless millions of men and women? What other way of life has brought the most rarefied of ideas and the most palpable of human realities into such intimate relationship? Religious faith has established a hotline from personal interiority to transcendent authority-an achievement upon which the advocates of culture can only gaze with envy. Yet religion is as powerless as culture to emancipate the dispossessed. For the most part, it has not the slightest interest in doing so. (2009: 165-166)

But what of Marxism's potential in reconciling culture and civilization? Eagleton responds as follows:

If Marxism holds out a promise of reconciling culture and civilization, it is among other things because its founder was both a Romantic humanist and an heir of Enlightenment rationalism. Marxism is about culture and civilization together-sensuous particularity and universality, worker and citizen of the world, local allegiances and international solidarity, the free selfrealization of flesh-and-blood individuals and a global cooperative commonwealth of them. But Marxism has suffered in our time a staggering political rebuff; and one of the places to which those radical impulses have migrated is - of all things-theology. It is in some sectors of theology nowadays that one can find some of the most informed and animated discussions of Deleuze and Badiou, Foucault and feminism, Marx and Heidegger. (2009: 167)

What I find most important in Marxism is its explanation of how capitalism works to necessarily exploit workers and the environment, provoking workers to rise up and 
replace capitalism with socialism and eventually the state will wither under communism. Both Jesus and Marx have an eschatological view of history and, as Michael Rivage-Seul (2008) notes, Jesus challenges us to reject the worship of a divinized violence that feeds the "satanic military industrial complex" and practice a non-violent form of resistance against differentiating wealth.

PJ: In your work you talk about the development of critical consciousness among students. What does this mean?

PM: A commitment to the oppressed leads to action in and on the world on behalf of the aggrieved of this world. Critical reflection on that action leads to what I refer to as protagonistic agency, a praxis of liberation. Protagonistic agency pulls out of the darkness of probability and potentiality the reality of social change, bringing it into the realm of actuality. Through a concentration of will - a type of hyper-intentionality - critical educators can submerge their ideas in their unconscious where they can confront their fears and traumas surrounding the risks and reprisals that they may face in their struggle for social justice. Such a struggle in the Golgotha of their hearts can direct their ideas into the light of reflective awareness without over-identifying with their feelings because these ideas have now been conditioned to ratify a new reality rather than remaining trapped by the old. This is fundamentally a dialectical process, an embrace of absolute negativity that leads to new beginnings.

PJ: There are many different religions in the contemporary world. Can we generalize emancipatory and educational potentials of Christianity to all religious systems of belief, or should we be more careful about such generalizations?

PM: The realm of religion is the realm of myth, symbol, art, mystery, legend, theater, and poetry - realms where we can delve deeply into the meaning of life. I am an ecumenist and do not believe God is revealed only through Christianity. I have helped marry a couple during an Umbanda ceremony in Brazil, have received an award for defending African-Brazilian religion from attacks by Christian evangelists, have visited Buddhist temples in China, Taiwan, and Malaysia, prayed at the Vatican and at indigenous churches throughout Mexico, visited Shinto shrines in Japan and mosques in Turkey, and dialogued in Pakistan with both Sunni and Shia Muslims.

Do we believe that the Christian God is monolithic? In the Christian Bible there is a plethora of gods - the God of Empire that Christianity has supported since the fourth century, the God of Eve, the God of Abraham and Moses, the God of Cain, the God of Satan, and the God of Jesus. According to Rivage-Seul (2008), Jesus is the prophet whose revelation ultimately decided that the God of Moses and Abraham (the God of the poor and the suffering) was the true God of Israel. Should we believe that the rich and the poor worship the same God? Take Hitler, for example. Hitler claimed to be Christian, but he only used "religious" language as a propaganda tool and he stated in Goebel's diaries that "as soon as the war is over" the Nazis will go after "the real enemy" - the Catholics. Pius XII referred to Hitler as "an indispensable bulwark against the Russians" (Johnson, 1977: 490, as cited in Rivage-Seul, 2008: 109). According to Rivage-Seul, the God of the Bible is not neutral and could not have been the God of both Hitler and Yahweh. Was the God of Ronald Reagan the same God as the God of Reagan's "Godless communists" - the Sandinistas? Are the God of Christian fundamentalism and the prosperity gospel not arrayed against Jesus who stands on the side of the poor and the oppressed?

Rivage-Seul (2008: 114) believes that liberation theology is closer theologically to the idea that God is experienced not just in nature but in history; is revealed primarily in Exodus; is 
concerned with justice as true worship; is class-biased in favor of the poor; endorses an ethic of love and self-sacrifice; protects freedom from exploitation; permits violence to defend the poor from exploiters; is anti-imperialist; considers the ultimate revelation of Jesus to be that God stands with the poor, and that an accumulation of riches presumes an engagement with forms of exploitation. We should always be careful about what we generalize to other religious systems of belief. If I were to generalize, however, it would be from the perspective of a theology of liberation. I would never want to generalize precepts and principles from any organization that serves mainly to strengthen and reproduce systems of power and privilege that serve the rich at the expense of the poor. To support the reproduction of the power and privilege of the rich would be counter to the teachings of Jesus, who was against any system that produced differentiating wealth or what some call today "economic inequality." Such a term is too weak for me. I would call it, plain and simple, capitalist exploitation.

\section{Declaration of Conflicting Interests}

The authors declared no potential conflicts of interest with respect to the research, authorship, and/or publication of this article.

\section{Funding}

The authors received no financial support for the research, authorship, and/or publication of this article.

\section{References}

Black D (ed.) (2014) Helen MacFarlane: Red Republican: Essays, Articles and Her Translation of the Communist Manifesto. London: Uncant Publishers.

Boal A (2008) Theatre of the Oppressed (Get Political). London: Pluto Press.

Boff L (1987) Passion of Christ, Passion of the World: The Facts, Their Interpretation and Their Meaning Yesterday and Today. Trans. Barr R. Maryknoll, NY: Orbis Books.

Boff L (1997) Cry of the Earth, Cry of the Poor. Trans. Berryman P. Maryknoll, NY: Orbis Books.

Butt R (2009) Pope claims condoms could make African Aids crisis worse. The Guardian17 March. Available at: https://www.theguardian.com/world/2009/mar/17/pope-africa-condoms-aids (accessed 26 September 2016).

Câ mara DH (2009) Dom Helder Câmara: Essential Writings. Maryknoll, NY: Orbis Books.

Chaudary A (2007) On religion and politics: Noam Chomsky interviewed by Amina Chaudary. Islamica MagazineApril-May, p.19. Available at: https://chomsky.info/200704 / (accessed 26 September 2016).

Dear J (2006) Ita, Maura, Dorothy and Jean. National Catholic Reporter5 December. Available at: https://www.ncronline.org/blogs/road-peace/ita-maura-dorothy-and-jean (accessed 26 September 2016).

Duchrow U (1999) Europe and global economic justice. In: Morton A and Francis J (eds) A Europe of Neighbors? Religious Social Thought and the Reshaping of a Pluralist Europe. Edinburgh: The University of Edinburgh, pp.125-140.

Eagleton T (2009) Reason, Faith and Revolution: Reflections on the God Debate. New Haven, CT, and London: Yale University Press.

Ellacuria I and Sobrino J (eds) (1993) Mysterium Liberationis: Fundamental Concepts of Liberation Theology. Maryknoll, NY: Orbis Books. 
Ford DR (2016) Review of Peter McLaren (2015) Pedagogy of insurrection: From resurrection to revolution. Texas Education Review. Available at: http://txedrev.org/wp-content/uploads/2016/04/ Ford_Final_pedagogy-of-insurrection-review_4-14.pdf (accessed 26 September 2016).

Freire P (1973) Education, liberation and the Church. Study Encounter 9(1): 1-16.

Freire P (1995) Preface. In: McLaren P (ed.) Critical Pedagogy and Predatory Culture. London: Routledge, pp.ix-xi.

Gutierrez G (1988) A Theology of Liberation: History, Politics, and Salvation. Trans. Inda C and Eagleson J. Maryknoll, NY: Orbis Books.

Hudis P (2015) Frantz Fanon: Philosopher of the Barricades. London: Pluto Press.

Jandrić P (2017) Learning in the Age of the Digital Media. Rotterdam: Sense.

Johnson P (1977) A History of Christianity. New York: Atheneum.

Kelly EF, Crabtree A and Marshall P (eds) (2015) Beyond Physicalism: Toward Reconciliation of Science and Spirituality. Lanham, MD: Rowman \& Littlefield.

Kelly EF, Kelly EW, Crabtree A, et al. (2007) Irreducible Mind: Toward a Psychology for the 21st Century. Lanham, MD: Rowman \& Littlefield.

Kosinski M, Stillwell D and Graepel T (2013) Private traits and attributes are predictable from digital records of human behavior. In: Proceedings of the National Academy of Sciences (PNAS). Available at: http://www.pnas.org/content/110/15/5802.full (accessed 26 September 2016).

Kovalik D (2013) US still fighting "threat" of liberation theology. Counterpunch, 5 March. Available at: http://www.counterpunch.org/2013/03/05/us-still-fighting-threat-of-liberation-theology/ (accessed 26 September 2016).

Laszlo E (2014) The Self-actualizing Cosmos: The Akasha Revolution in Science and Human Consciousness. Rochester, VT, and Toronto: Inner Traditions.

Marcuse H (2011) The role of religion in a changing society. In: Kellner D and Pierce C (eds) Psychology, Psychoanalysis and Emancipation: Collected Papers of Herbert Marcuse, Volume 5. Oxon and New York: Routledge, pp.182-188.

Marx K (1970 [1843]) Critique of Hegel's Philosophy of Right. Trans. Jolin A and O'Malley J. Cambridge: Cambridge University Press.

Marx K (1981) Capital, Vol. III. New York: Vintage.

Marx K and Engels F (1848) The Communist Manifesto. Available at: https://www.marxists.org/ archive/marx/works/1848/communist-manifesto/index.htm (accessed 26 September 2016).

McLaren P (1999) Schooling as a Ritual Performance: Towards a Political Economy of Educational Symbols and Gestures. Lanham, MD: Rowman \& Littlefield.

McLaren P (2015) Pedagogy of Insurrection: From Resurrection to Revolution. New York: Peter Lang.

McLaren P and Jandrić P (2014) Critical revolutionary pedagogy is made by walking - In a world where many worlds coexist. Policy Futures in Education 12(6)831.

McLaren P and Jandrić P (2015) The critical challenge of networked learning: Using information technologies in the service of humanity. In: Jandrić P and Boras D (eds) Critical Learning in Digital Networks. New York: Springer.

McSherry JP (2005) Predatory States: Operation Condor and Covert War in Latin America. Lanham (MA): Rowman \& Littlefield.

Miranda JP (1974) Marx and the Bible: A Critique of the Philosophy of Oppression. Maryknoll, NY: Orbis Books; Oxon and New York: Routledge.

Miranda JP (1977) Being and the Messiah: The Message of St. John. Maryknoll, NY: Orbis Books.

Miranda JP (1980) Marx against the Marxists: The Christian Humanism of Karl Marx. Trans. Drury J. Maryknoll, NY: Orbis Books.

Miranda JP (2004) Communism in the Bible. Trans. Barr RR. Eugene, OR: Wipf \& Stock.

Reitz C (2015) Philosophy \& Critical Pedagogy: Insurrection \& Commonwealth. New York: Peter Lang Publishers.

Rivage-Seul M (2008) The Emperor's God: Imperial Misunderstandings of Christianity. Radford, VA: Institute for Economic Democracy Press. 
Rivage-Seul M (2016) Chomsky on U.S. war vs. liberation theology. Available at: https://mikeriva geseul.wordpress.com/2012/04/28/chomsky-on-u-s-war-vs-liberation-theology/ (accessed 26 September 2016).

Robinson WI (2004) A Theory of Global Capitalism: Production, Class, and State in a Transnational World. Baltimore, MD: Johns Hopkins University Press.

Robinson WI (2014) Global Capitalism and the Crisis of Humanity. New York: Cambridge University Press.

Robinson WI (2016a) Sadistic capitalism: Six urgent matters for humanity in global crisis. Truthout, 12 April. Available at: http://www.truth-out.org/opinion/item/35596-sadistic-capitalism-six-urgentmatters-for-humanity-in-global-crisis (accessed 26 September 2016).

Robinson WI (2016b) Reform is not enough to stem the rising tide of inequality worldwide. Truthout, 1 January. Available at: http://www.truth-out.org/news/item/34224-reformis-not-enough-to-stemthe-rising-tide-of-inequality-worldwide (accessed 26 September 2016).

Rohr R (2016) The path of descent. October 16. Center for Action and Contemplation. Available at: http://centerforactionandcontemplation.cmail19.com/t/ViewEmail/d/A2C391CB09818C45/ 12E9998DA07E136EC67FD2F38AC4859C (accessed 26 September 2016).

Sobrino J (2001) Christ the Liberator. Maryknoll, NY: Orbis Books.

Teilhard de Chardin P (1959) The Phenomenon of Man. New York: Harper and Row.

Teilhard de Chardin P (1964) The Future of Man. New York: Harper and Row.

Teilhard de Chardin P (1965) The Appearance of Man. New York: Harper and Row.

Teilhard de Chardin P (1966a) The Vision of the Past. New York: Harper and Row.

Teilhard de Chardin P (1966b) Man's Place in Nature. New York: Harper and Row.

Teilhard de Chardin P (1968) Science and Christ. New York: Harper and Row.

The Rockefeller Foundation (1969) The Rockefeller Report. Available at: https://www.rockefeller foundation.org/app/uploads/Annual-Report-1969.pdf (accessed 26 September 2016).

Williams R (2014) Bonhoeffer's Black Jesus" Harlem Renaissance Theology and an Ethic of Resistance. Waco, TX: Baylor University Press.

Youyou W, Kosinski M and Stillwell D (2015) Computer-based personality judgments are more accurate than those made by humans. In: Proceedings of the National Academy of Sciences (PNAS). Available at: http://www.pnas.org/content/112/4/1036.full.pdf (accessed 26 September 2016).

Peter McLaren, is a Distinguished Professor in Critical Studies at Chapman University, USA, where he is Co-Director of the Paulo Freire Democratic Project. Professor McLaren is the author and editor of nearly 50 books and hundreds of professional publications on education and social justice. His writings have been translated into over 20 languages. One of Professor McLaren's recent awards includes the Outstanding Educator in America Award presented to him by the Association of Educators of Latin America and the Caribbean. Correspondence: peter.mclaren1@gmail.com

Petar Jandrić, is a Professor in Digital Learning and Programme Director of BSc (Informatics) at the Zagreb University of Applied Sciences (Croatia), and visiting Associate Professor at the University of Zagreb (Croatia). His research is focused to trans-disciplinary collaborations at the intersections between critical pedagogy and digital cultures. Petar published three books, dozens of scholarly articles and chapters, and numerous popular articles. His writings have been published in several languages.Correspondence: pjandric@tvz.hr. 